\title{
The Improvising Judge: An Interview with Her Honour Judge Patricia Smyth, Northern Ireland County Court
}

\author{
Sara Ramshaw and Seamus Mulholland
}

\section{Background}

Her Honour Judge Patricia Smyth (HHJ Smyth) studied at Queen's University Belfast and was called to the Bar of Northern Ireland in September 1986. She practiced as a barrister between 1986 and 2002 in a variety of areas within the legal professions such as criminal law, civil law, and employment law. In 1998, she was appointed as Chair of the Northern Irish Industrial Tribunals and Fair Employment Tribunal and its Vice President in 2007. HHJ Smyth was appointed by Her Majesty the Queen and sworn into office before Sir Declan Morgan, the Lord Chief Justice of Northern Ireland, on February 1, 2010. For the past three years, she has specialised in family cases, particularly public law family work, which involves cases of the state intervening in family life.

HHJ Smyth has been hugely supportive of the Into the Key of Law research project, ${ }^{1}$ contributing as an interviewee and a focus group/improvisation workshop participant with other legal and social work professionals. She was also a panelist at the May 2015 symposium, "Just Improvisation: Enriching child protection law through musical techniques, discourses and pedagogies,"2 at Queen's University Belfast, Northern Ireland.

Seamus Mulholland is a Northern Irish barrister (Year of Call: 2012) and Sara Ramshaw is an Associate Professor at the University of Victoria Faculty of Law, Canada (formerly of Queen's University Belfast School of Law).

This interview took place on Wednesday 22 June 2016 at the Newry Courthouse, Northern Ireland.

\section{Improvisation and Child Protection Law: Some Initial Thoughts}

Patricia Smyth (PS): As it turned out, I was at a family funeral in March this year [2016] in England, and I discovered that my uncle had been a traditional fiddle player all his life. At the wake, a number of Irish traditional musicians came together to play. I was told that the group had never played together-ever. But, each of them had played with my uncle. I sat and watched for about 3 hours in the context of your project [Into the Key of Law]. Because, for example, I had always thought Irish traditional music people would be drinking alcohol and it was kind of "free for all"-people just did their own thing. You had been at pains to point out that that is not improvisation. That became clear at the [improvisation] workshop. ${ }^{3}$ What I observed at the wake was it seemed by tacit agreement one person would generally take the lead, but then other people would come in at various times, and then people would step back. But, people were listening for cues the entire time. So, I was watching this in the context of your research project...

Sara Ramshaw (SR): Very good!

PS: . . . because it was something entirely new to me. I did reflect on this in the context of child protection. This is just my own personal view, but I think how well the system works depends on the personalities of the social workers involved, of the guardians, of the judges, and of the legal representatives. I have seen this approach work really well in cases that I have done. I have seen a group of us work collaboratively and really listen to what each of us was saying about the factual situation, and being open to say, "okay, we came into court with this view, but, having heard what you say, we actually think maybe a different approach might work." A real openness. When that collaborative approach is working well, it is: a) terrific, but also b) probably the safest thing for a family. Because child protection work is extremely risky business for all of the professionals.

I don't know whether you saw the headlines today in The Times 4 of a case where a father killed his daughter after abusing her for years in circumstances where, following the father's acquittal of charges for severely shaking his daughter, the case then went to the family court. The High Court family judge said not only that the allegations couldn't be proved, but that this man was innocent and that this child must be returned to him. The Judge wrote a letter to make sure that, if social workers tried to carry out any investigation in the future, action could be taken against them. Well, the judge was wrong. The father went on to kill his daughter. That brings home the risky business that we're all involved in.

The difficulty for a judge is we are getting snapshots from the professionals, and we're making judgments very often based on those assessments. We don't actually go out and see the home ourselves. We don't see the contact that takes place between a child and a parent. Everyone's very nervous in the system, and I think that 
explains why people are much more comfortable with a set approach that they believe will be the safest way for the professional: "I'm covered, if anything goes wrong in this case." That's just a fact of life.

As I said in my original interview for the Into the Key of Law research project, what appears to be the safest thing physically may not in fact be the safest thing emotionally for the child, and in fact may be hugely damaging for the child. So, I think this is why people are much more comfortable with strict rules. That's what I see in the family courts, having come from it fresh: research says $X$ in these circumstances, therefore we do $X$, and then no one can criticise us. I am quite sure judges take that view as well. But, as I say, there were so many situations where I can see that, although a child may be protected from physical harm, that child would be destroyed emotionally, if we take that path. So we need to find a new path! These were just some of my ideas. When improvisation works really well, it probably is the safest thing for children, but the difficulty is I think so much of it does depend on personalities.

SR: Which I am sure it does in music as well, whether the improvisation works or not?

PS: Yeah.

PS: When I thought about what I learnt from watching the Irish musicians play, and what that might mean for child protection, I thought what it means first of all is being able to spot shafts of light, for example, in a case. Because very often, as things emerge, there can be turning points in people's lives, even against a very black background. There can be something that happens that actually changes a parent's whole insight into their parenting ability. For example, a new partner. A new partner who isn't abusive. Who is supportive. That one factor can actually make an enormous difference. And I can say that certainly it is now recognised within the system that we do need new approaches to child protection.

One of the big success stories in England and Wales, as I understand it, is the emergence of problem-solving courts. Lord Justice Gillen in Northern Ireland is currently carrying out a review of family and civil justice, and I was part of the subgroup that wrote a paper on the difficulties that we saw in the system, things that needed to be improved, and made recommendations for improvement. In due course, that paper, along with all of the papers, will, I think, be published as part of the review. ${ }^{5}$ But, one of the things certainly I have recommended in the paper that I wrote was that we should introduce problem-solving courts. Just to explain what that means: in a case where, for example, the root cause of a parent's inability to parent is drug addiction, if you can solve that problem, you can deal with all the other things that flow from that. If you can't solve that problem, then you can't solve anything. The approach of the problem-solving courts is a much more collaborative approach. Where the lawyers are in at the beginning, but they're not in at every hearing. The judge holds all of the interdisciplinary team of experts accountable: they inform the court of how things are going. It's quite a different approach, but, in many ways, it is similar to what you are talking about. You know? Hear! Listen! And, respond appropriately. And, it's actually a very difficult thing to do.

Seamus Mulholland (SM): Is that going to be interesting for you as judges, if the lawyers aren't involved all the time? You're going to be hearing litigants' voices and directly dealing with them. Is that going to be exciting hearing those voices directly, if you're holding it all together, and the lawyers aren't running it so much?

PS: Yes, it probably will be, but you see, my approach has always been to engage with people directly, even those with lawyers. I didn't speak to people without the presence of the lawyers, but I think it's important. These are peoples' lives that we're dealing with. The people are sitting there in front of you, and I certainly as a family judge would never have taken the view that I should ignore them as people and speak directly to the lawyers. I would frequently_frequently_speak to parents and say, for example, "Look, let me explain this to you. There is an issue of drug addiction here. There is an issue of alcohol abuse. Now, you want your child back. I can't give you your child back unless I am satisfied that your child will be safe and that means that I have to know that you're taking steps to deal with this problem you have. There's lots of help available here for you. We want to help you. That's what the social workers are offering, but you need to take that help." Or, I would explain to a parent who is very angry and upset and thinks the social workers are always picking on her, I might say, "Now, can I just explain something to you. It's not a weakness to put your hand up and ask for help. It's a strength." Which it is. Sometimes the parents would listen to what I would say, even though I am just saying the same thing as the social worker, because I would go to great lengths so that I would be seen as fair and impartial to the parent. So, sometimes I can get the message across that the social workers had been trying desperately to.

To come back to your point, I don't know. It'll be interesting. But, as I understand it, one of the benefits, and one of the ways in which the problem-solving courts work, is that the experts build a relationship of trust with the parent because there has to be a relationship of trust in order for any parent to really properly deal with whatever the problem is. I mean it could be domestic violence, which is a huge issue in these types of cases. So, it might be that the problem is that the mother needs to, really for the first time, understand that it isn't acceptable to be treated in that way, and to raise her self-esteem. If that problem is going to be sorted, there has to be a 
relationship of trust between her and the people helping her. I am very excited about that development, and I know that it's a recommendation that is finding favour with the Department of Justice and with other the government departments.

SM: So, they're going to resource it as well because presumably it's going to take a good bit of . . .

PS: The issue is always going to be resources, but at least if they're keen that this is a very good idea. That's the first step. I know from a recent conversation that we're hoping that something will come of that.

SM: Fantastic!

\section{Training the Improvising Judge}

SM: You said previously that you came to judging with no experience of family law.

PS: Yeah.

SM: So, you just sort of found what you thought to be the right way of it?

PS: Well, I came to it with very little practical experience but a great deal of knowledge. I was very well trained in England at the Judicial College. I think that's very important. No judge in Northern Ireland is allowed to do family work without the appropriate training. The course that I attended-well, two courses-were both extremely intensive. Two weeks in total. Two full weeks. They required a great deal of preparation beforehand. An excellent training course covering every aspect of the law and how to deal with issues that typically come before the family court. So, I think it's important to say that all of my work is based on a thorough understanding of the legal framework. The other issue is that we have a very collaborative working relationship within the judiciary. There is a very relaxed and informal communication structure between judges and we do talk about issues, and we can talk about problems within cases. So, we can share a wider network of knowledge and experience. That's how we work. The Judicial Studies Board also ensures that judges receive up-to-date training in all areas.

SM: The second question I had was-I think we spoke about this before-as you've went along, it seems like you've realised what our project of improvisation is about. Have you had experience of improvisation in the past in terms of musical improvisation?

PS: Musical? No. I have no musical experience of any kind. Couldn't read a note.

[Laughter]

SM: But, were you aware of improvisation as a concept, or an idea?

PS: I knew the term, but I didn't understand it. If you had have asked me, "What's improvisation?" I would have said, "Everyone just does their own thing."

SM: Yeah.

PS: So, my understanding was completely wrong, and I actually think that will be your biggest challenge.

SR: That's why we have to start every talk or paper with: "It's not just making it up as you go along."

PS: Absolutely.

SR: So, we're going to entitle this interview, "The Improvising Judge."

PS: Right.

SR: We're wondering your thoughts on whether that excites you as a title, or whether that makes you a bit uneasy?

PS: Oh, it excites me. It excites me. It's such important work, and it's so important that each family is treated as a unique unit. I mean there is no question that all of the professionals need to be informed by research. Research 
is vitally important, and there's no question that a lot of the approach that I took was informed by research. I mean, for example, at a BAAF-the British Association of Adoption and Fostering - event there was research given by, I think it was one of the lecturers at Queen's in social work, whose name escapes me ... it had such an impact on me. Ironically, it had such an impact on me that I improvised.

SR: Ah, okay!

PS: Because the research was about the percentage of children in care who felt that they did not have enough contact with various family members, and they listed them: the percentage of children who didn't feel they had enough contact with their birth mother; the percentage who didn't have enough contact with their siblings; their grandparents; their aunts and uncles. And, it listed all of this. The statistics were quite staggering. That really impacted me because I began to think that the voice of the child perhaps wasn't being heard in the process, and that again is an issue that Lord Justice Gillen is specifically addressing in his review about the voice of the child, and the importance of hearing it. I was chairing that event and the question I asked the audience, which was made up of social workers and lawyers, was, "Are we getting contact all wrong? Look at those statistics. If that's how children feel, are we getting it wrong?" And, one of the panel members-a very experienced social work professional/academic — said, "No, no, no, we're not! We're not getting it all wrong! You don't give a child what the child wants, if it's not in the child's best interests." And, I'll tell you truthfully my heart sank. It really did. Now, thereafter, the approach I took-and this, in terms of improvisation-to every case or most cases was where is the child coming from in this? Can I achieve what this child wants? It may be that I can't. It may be that it wouldn't be safe, and lots of children desperately want to be returned to their birth family in situations where it wouldn't be safe to return them, but I start from that point of view: can I achieve what the child wants? And, I see nothing wrong with starting from that viewpoint because it doesn't prevent me properly evaluating the risks in the case. It's just an acknowledgment that, if I can achieve what the child wants, then is that not what I should do? I don't know whether or not other people approach it from that, but that's just what I decided to do. But, it was largely based on that research. So, I'm the first to acknowledge the importance of research.

SM: You're saying that there is the need to see each family as a unique unit. Do you think that improvisation is about this ability to see these people as unique identities, and see everything that can possibly be there for them?

PS: Yes! It's a unique family, it's a unique problem and it needs a bespoke solution.

SR: After participating in our project, and you've said several times even in this interview, your view of improvisation has changed. If you were to describe how you view improvisation now, how would you do so?

PS: I would say, "Let's forget what we normally do in a situation like this. Let's go back to first principles. Let's look at the history of this case, and let's look at any progress that has been made, and let's look at where we are today in this case, and let's think about a range of possible solutions, and let's look at each of those possible solutions with an open mind. Let's park any negative assumptions we have. Let's, as a group, with an open mind, reflect on each of them."

The problem is-and this is why pre-proceedings ${ }^{6}$ are so important-by the time everybody gets to court, everybody is in their corner, and everybody is trying to defend where they're coming from. And we need to come out of those corners without feeling that we're going to be criticised. I think social workers are very nervous about being criticised by judges. Now, perhaps there has been too much criticism in the past? And, perhaps there still is? Because there is no question social workers need to feel confident that they can change their mind. They are afraid to change their mind, and I always encourage social workers, in view of the discussion or how things have changed from one hearing, not to feel that that it is a sign of weakness or that it would reflect badly on them. In fact, as I have said to social workers, "I think much more highly of you, if you're prepared to say, 'actually, I've never thought of that." So, that's how I would describe maybe the optimum, or the optimal, situation for judicial decision-making.

SM: If that's the optimal situation, which The Improvising Judge brings about, then is that something that judges should take pride in, that when you bring about a situation like that, where people are willing to change their minds?

PS: Oh, yes! Oh, yes! Some of the greatest senses of achievement I have had was where we did an about turn by agreement, and there are lots of those cases. Lots of them.

SM: You're saying that often there are cases where you have the goal in mind and you're working towards it. So, if that's the case, then perhaps "The Improvising Judge" is what people should look at more thoroughly and see what it's about? And maybe aspire towards that? 
PS: It's an enormous responsibility and the buck stops with the judge. But it is the judge's responsibility to make sure that the decision-making process is fair and is appropriate. There's just no getting away from that.

SM: But is your view that too often people are setting out with an idea of where they're going to end up, and everything that goes on in between is getting to that point really?

PS: I do think that. But I want to say this in favour of the social work profession. They work under enormous pressure. I want to make that absolutely clear. They work under enormous pressure, and their resources are constantly diminishing. Yet, they are dealing with the most high-risk work that people can do. So, I am very anxious in this discussion not to appear critical. Your point is, well, maybe a decision is taken very quickly: "Look, there's no chance here. Or, we'll give them one chance and, if it doesn't work, that's it. Into court. Order. Deal done." And, that's because of the awful situation social workers work in. There isn't the time. So, it's so easy, and also human nature-you know, we all do it. I'm sure I do it as well. I have to be very, very careful in my decisionmaking for every case. I have to be very careful that I am properly evaluating the evidence and it's in every sphere. I have a very difficult criminal case ongoing at the minute and there was a very difficult legal issue that had to be determined. It was only when I had set out very carefully all of the evidence and stepped back and properly evaluated it that I reached a conclusion that I initially didn't really want to reach in the case. Instinctively, I felt the right decision was $\mathrm{X}$, but judges have to make decisions based on evidence. It's not always easy to do, but you must do it, and you must be aware that there's a tendency in human nature perhaps to reach a conclusion that isn't based on the evidence. The same is true of all professionals.

SR: So, in light of your description of improvisation-that's so helpful to also put it into the actual legal contextwhat do you think in those situations is the work or the skill that would go into improvising?

PS: It requires huge intellectual capacity. It's exhausting work because it requires huge concentration ... to hear and listen and then assimilate what that means. What it may mean. What it may not mean. What the options are as a result of what you're hearing? Huge concentration. Huge, hard work.

SM: Do you think there's a skill as well in even just finding time to reflect properly because I know whenever I'm doing something I can look at it one night and think l've got it right, but then come back to it tomorrow and realise that I was just tired or something. So, maybe there's a skill in finding space and time to do that?

PS: I agree.

SM: Especially when you're busy?

PS: I agree entirely. One of the recommendations that I have made is that judges need to be given space to do their work. Social workers need to be given space to do their work. I have said that expressly. Fortunately, a judge is always required to give reasons for decisions so the decision-making process is clear.

In the three years that I have done this work, despite a heavy workload, I have always made sure that I gave myself enough time to take the decision. Always. Now, that meant that I might have to say, "I'm going to reflect on this and I'll give my decision in a week." Or, it might be that I would say, "I would like to hear from another witness before I make my decision." The benefit of being the judge, that probably no other professional has, is that I control my own workload. Now, you mightn't think I control it because of my lists, but I do have control over it. So, it's using that control appropriately.

I remember a case that I'll never forget, a case where both parents had severe mental health issues. The mother's mental health had essentially deteriorated on a post-puerperal basis, post-natal depression. That was the major issue. And I had the barrister for the Trust ${ }^{7}$ and the barrister for the Guardian ad Litem ${ }^{8}$ who were effectively stamping their feet and demanding that I reach the decision now. I felt I was being pushed. And there was a psychiatrist and he was saying, "No hope. No hope." A clinical psychologist gave evidence in that case. She approached the case from a completely non-social work background and what she said was, "Let's wait and see what happens in three months' time." Because in three months one of two things will have happened here. If one thing happens, well, we do know where we are, but, if that doesn't happen, then we might be looking at a different situation. And despite the stamping of feet and the growls of barristers, we bought three months' time. We came back in three months and the situation was not as dark as everybody said it was going to be. And the psychiatrist said, "No. No. That hasn't happened. That's right." The thing that he said was definitely going to happen hadn't happened. The lawyers were still stamping their feet: "No. You don't understand there's another child involved here. The pressure. We need a decision now. We need a decision now." Well, I said, "No. No. No." I had two professionals on side now [the psychiatrist and the psychologist]. I said, "No. No, we'll wait and see." The child had been removed from the parents' care. She was about a year and a half, maybe, and then there was the new baby. It was all about the mother, whether her mental health would deteriorate or not deteriorate after the birth of the new baby. That was the crux and that's how we bought time. The way that case ended up 
was everybody agreed that both children should go back to that family. Everybody agreed. I didn't even have to make an order. But that was against the background of everybody demanding that I take that decision. In fact, the solicitor who was acting for the Guardian, she sent me an e-mail last year to tell me how well everybody was doing and the first child was at school.

SM: Wow.

SR: That's great.

PS: But again the responsibility lies with the judge to ensure there's appropriate time and we can control that. It's not easy, but we can do it.

SM: It sounds like what you're saying is about finding the shafts of light. It's almost like saying, "Don't make your decision in the darkest moments. If you see any potential for light, wait until you get out and see if it's actually there..."

PS: Or whether it's a shadow and it isn't there. You must be very alert to that.

SM: Yeah, that's nice.

SM: What I was wondering is, if part of improvisation is listening to other people, listening to your colleagues, if you're going to make a decision on a point of law, and then maybe give a judgment on it, will you speak to other colleagues about that, or will you always be fiercely independent? How do those two things relate?

PS: There is a distinction between talking to your colleagues about issues and being judicially independent. There's nothing wrong with hearing different points of view. That doesn't impact on judicial independence. What matters is, ultimately, that when you have reflected on all of the evidence, all of the issues, anything that someone might have suggested you might want to think about, you're responsible for your own decision. Sometimes if I talk about an issue to my colleague, even talking it out, helps me to get clarity in my own mind. That's the purpose of talking to your colleagues: so you get things clear in your own mind. But, when I reach a decision, that's my decision and I'm responsible for it.

SM: You were saying earlier that you looked through the evidence in your criminal case and had to come to a decision you didn't really like, but that's where you came in the end.

PS: .Yes, that is because every decision has to be arrived at judicially, which means applying the law to the relevant facts. Interpreting and applying the law correctly will determine the outcome of the case.

SM: So, is there any way to improvise and find subtleties that distinguish, and let you loose from the binding judgment, if you can find something new that wasn't really in that judgment? That justifies it?

PS: Well, I think, in family work the legal principles are broad and every case is fact specific. How the law and its underlying principles applies, and the correct outcome, will be different in each case

SM: I suppose, even not on a point of law, but the statutory requirements, you know, No Delay ${ }^{9}$ and all that, are interpreted differently in different cases, aren't they?

PS: Well, no, you see the issue is how the law applies in a particular case. The facts of the case. The No Delay principle means that there must be no delay that can't be justified in terms of the "welfare of the child." So, delay that is purposeful is, of course, not only permitted, but necessary. Certainly, the legal principles of family law do not tell me what the outcome must be of any case. They assist me in how I should approach the case, but the welfare of the child in every case will be different.

SM: So, they're actually encouraging you to, as you say, see each case as different.

PS: Oh, absolutely. The legal principles are helpful. They provide a very helpful framework within which to consider the issues in the particular case, but they're not restrictive in a way that would be detrimental to a child. The purpose of the law is to enable decisions to be made in a child's best interests, whatever that may be, taking account of the rights of family members.

\section{Limits to Improvisation in NI (Family) Law}


SR: I want to return to the "Just Listening" symposium and to the comments made by Judge Sherrard" on your panel. He very much emphasised the limits to improvisation in terms of precedent and legislation. He talked about resources. He talked about the limited number of options available to a judge. He was very much focused on the things that are limiting his ability to be creative, or to improvise. But you disagreed with that position and you actually said that you thought that there was "huge scope for improvisation, flexibility, [and] creativity, to get the right solution to an individual family problem." So, we were wondering whether you could speak a bit more on what you see as the current limits to creativity, flexibility and adaptability and how you might rethink these limits as actually offering potential opportunities for more just, or case-specific, decision-making?

PS: I think Judge Sherrard and I are talking about two different things. He's absolutely right, for example, there is a limited range of orders that can be made, and, if the evidence does not justify one of those orders being made, then you cannot make any order. He's absolutely right in terms of the statutory framework. But, I think I was thinking about something different, so we're not actually at odds. What I am thinking is the two mains issues for any child are: where will the child live; and what contact will that child have with family members? So, within those two areas, there is huge scope for creativity. For example, I had a case that came to me on appeal from a decision of a wonderful district judge and the Trust had made an application for a care order ${ }^{11}$ with the removal of the children. The issue in the case was domestic violence between the parents, and it was very, very severe domestic violence. The District Judge had refused to make the order removing the children. The Trust appealed. On appeal, the Guardian, who was a wonderful, a wonderful woman, came in and explained, "Look, absolutely, there is a major issue here of domestic violence. We have tried. These parents have been given every opportunity to have educative work. We've spoken to each of them individually. We've tried to get the mother to see through the Journey to Freedom course that Women's Aid ${ }^{12}$ run to help address low self-esteem. We've tried to work with her. We've tried to work with him. We've tried, we've tried, we've tried, we've tried!" And I said, "Yes, I know that. But, let's look at this situation. The problem in this case is that the children are being exposed to domestic violence. We're all agreed that that cannot be allowed to continue, but my solution is that the father is excluded from the family home and the children remain in their home with their mother and their grandparents in familiar surroundings. Take him out of the picture. Don't take the children out." Now, I think that's an example of two completely different ways of solving the same problem. Achieving the same end. One course will protect the children emotionally. One will expose them. But the Trust wanted the one removing the children. So, that's an example of judicial creativity.

Another example of creativity is in relation to contact arrangements. Probably because of that research I told you about contact became something that I regarded as just as important as the main issue of whether or not there would be a care order. Contact and contact between siblings. There are two reasons why, I think, contact can be forgotten. One is that there's so much focus and concentration on where will the child live? And, that can take up all of our energy. The second issue is resources. It takes an awful lot of resources within a Trust to provide the best contact arrangements for children. I would look at-when you talk about creativity-for example, that we're not just talking about contact between parents and children. We're not just talking about immediate siblings. What about grandparents here? What about their cousins? Gosh! You never hear a word about cousins.

I remember one of the early cases, when I was coming to this fresh-and, it's a terribly sad case because it was a child who was being cared for by grandparents because the parents couldn't care for the child. And it turned out after blood tests that they weren't the grandparents. They were devastated. Devastated! I think the child was going to be adopted and the Trust said, "There's no need for any contact arrangement between the child and these people because these people who thought they were grandparents, they're not." And I said, "Hold on a wee minute. This child currently hasn't got a friend in the world. Now, these people love this child. These people may not be blood relatives, but they love this child. I see no reason why this child shouldn't be able to avail of the love anymore." So, that's what I mean when I talk about creativity within the confines of strict orders. So, Judge Sherrard and I were talking about two different things. They're both correct. In fact, Judge Sherrard is the most creative judge you will find, and the most careful and considerate judge. So, we're talking about two different things.

SR: Improvisation needs both, right? It needs to go beyond the strict structures to be creative, but it also needs those structures, those limits, from which to improvise off of. I just found interesting that you took the opposite approach to Judge Sherrard, and focused on the creativity that could come from the limitations. Both freedom and limits are needed to be improvisation, but it just depends on your focus.

PS: Yes, yes. Judge Sherrard is a very talented academic as well. He is absolutely right in particular about one issue and that is, unless the threshold ${ }^{13}$ is met for the intervention by the state, then there is nothing that can be done, even if you think that a family would benefit from that kind of intervention. So, he's absolutely right that, first and foremost, before you begin to be creative, you must be very careful to ensure that threshold facts have been proved. Only at that point can you really look at where you're going. That's very important because the state must not be allowed to intervene in any family unless there is a legal justification. So, he's absolutely right in that. 
SM: You were talking about the Trust barrister coming in, stamping his feet and banging, saying, "I need a decision. I need a decision." My questions is: whenever you come up against someone inflexible or uncreative, how do you deal with them? I know you were saying at one point you had first of all one professional on your side, then you had two. Was that the leverage that enabled you to say, "No, I'm not going to that." Or is it just standing your ground?

PS: Well, in the case that I told you about, had I not had the Clinical psychologist and her input initially, I would have been very hard pressed to justify adjourning the case for three months. Her input was really vital. As a judge, as I've explained, everything I do has to be based on evidence and I have to give reasons. So, it's not open to me to say, "Well, I'm deciding to do X, just because I have decided to do X."

SM: But could your justification or reasons be, "Look, I want to try to find a solution here. This is a very bad time. Things look bad at the moment, but, if we just take a little bit of time, it might improve, and I think that's a worthwhile thing to do, as a reason in itself"?

PS: Yes. I could have, and I don't know what l'd have done in that case had I not had the Clinical psychologist. I may have said, "Well, I appreciate the psychiatrist feels that it's almost inevitable that the mother will have another breakdown when the new baby comes, but let's just wait and see." I could have done that. But I am very aware that the professionals are highly trained in their field and I am also very conscious that their views and their assessments have to be accorded appropriate respect. So, I don't just go into court and say, "Well, you know what, you all think X, well, I think Y." That wouldn't be appropriate.

SM: No. But, it's interesting how much new ground has been covered with that issue. Even with contact. You know, that cousins weren't looked at, and all these people. And it's just because no one ever did it. So, it's just whoever identifies the opportunity first and then seizes it and you take it?

PS: Well, I don't know. Maybe other judges always looked at this issue, but the feedback came to me, "Oh, you know, your woman in there, you'd better get your contact arrangements sorted out." Which made me think that maybe it wasn't widespread. See judges, we're always so busy doing our own stuff. I don't have the opportunity to go in and watch another judge, which would be very helpful a lot of the time to see what another judge does. That's why we need to communicate, so that we can share best practice and how we deal with particular problems that arise.

One of the recommendations that I have made as part of the Civil and Family Justice Review is that there needs to be multidisciplinary training on a formal basis. We've had it here and there, but this is something that I see has to be formal, has to be structured, has to be ongoing so that communication structures between the various professionals are maintained, and that there is constantly fresh research, experience, good practice being shared. There's not enough of it, I think.

SR: I wanted to return to something you said in the Symposium. You said you were struck early on in your family law judicial career that ... I'll just quote you: you were struck as to the "rule-based, textbook approach that social workers and other professionals brought to the resolution of an infinite variety of family problems." You were talking specifically about social workers—but, I am wondering whether it applies equally to lawyers? Do they take more of a textbook approach?

PS: Yes. An example is, in Northern Ireland, it is the norm to have post-adoption contact with birth families. That's the norm. It's still relatively rare in England and Wales. Now, at a conference I was at, the feedback from the English professionals was that they would never be able to find adoptive carers if this link was maintained. But the whole issue of adoption is far from straightforward. It can work wonderfully well, or it may not. It can happen that a child who is adopted pines for the loss of a link. So, it's not straightforward, and I think generally speaking our courts have taken the view that it is in the best interests of children to maintain some kind of contact with the birth family. When I would have adoption ceremonies, where the adoptive family becomes legally one family, I have talked to lots of adoptive parents. On the whole-l'd say even more than on the whole-once it's explained to them, the insecurity of having this link dissipates. And I know adoptive parents who have built very constructive relationships with the birth parents.

Now to come back to the question you were asking me about rule-based approaches. I think there is a resistance to maintaining contact with the birth parents by social workers generally. I appreciate that none of us have a crystal ball here, and none of us can say for sure whether or not it'll be best that there is a complete cut-off, or best that there's some link. Nobody can say for sure. It's people we're talking about and it may depend on the circumstances. It seemed to me that the general approach of social workers is, "Well, if you're not good birth parents, you can send a Christmas card once a year, or Christmas and a birthday card. If you're good and behave yourself, you'll be able to have direct contact once a year. If there's a bit of a bond between you and the children, and the child is maybe six or seven, and you're good, you'll get it twice a year. If there's a really strong 
bond with the children, and the child is seven or eight, we'll give you three to four." I don't think that there's anybody who would disagree that that is generally how it pans out. If that isn't rule-based, I don't know what is!

\section{Creativity and Bespoke Solutions}

SR: You mentioned in the "Just Listening" symposium about your frustration over the textbook approaches by professionals in the court. As a mother of four children, you knew that it could not be right that the same answer as regards to, for example, how much contact a child needed with his or her parents, even if she or he had been removed from the family due to neglect or abuse, could be the same for every child. You explained that, as a judge, you have "huge scope to be creative"-if you actually want to do that and want to look at the various ways a problem can be looked at differently.

As you may recall, the audience members, both legal and social work professionals and improvising musicians alike, were incredibly intrigued by your openness to creative judging. I was particularly interested in your comment about how judicial decisions in child protection law are "hugely risky" and although they are, of course, evidence-based and reliant on pre-existent laws and rules, you said you thought, and I quote, there is "huge scope for creative thinking once we recognise that every child is an individual, every family problem is individual, and needs a bespoke solution".

I was wondering if you could expand upon this statement or the process of negotiating between the pre-existent, general laws that are supposed to apply equally to everyone and the singularity or uniqueness of every case?

PS: Well, again, the beauty of family law is that the principles are wide. The welfare of the child is the paramount consideration. Now, once that's the paramount consideration, I mean, how do you find out what is in the best interests of the child? Well, first of all, you'd need to ask the child. I wonder in how many cases does anyone say to the child, "How often would you like to see your mummy, or your wee brother?" Or, the foster carer, for example, might happen to know that this little girl is very attached to her baby brother in particular. So, this child might need to see her baby brother more often than she needs to see her older sister. Now, that's the kind of creative detail that needs to be worked on. Otherwise, you have a little girl who goes to sleep crying because she hasn't seen her baby brother in 2 weeks.

SM: In the family cases I have done, parents get really cross with that too, saying, "No one is listening or asking my child," "This is what I think they want," and "It's what they tell me." They ask, "Will the social worker go and ask how much time they want to spend with me or daddy, and with their brothers and sisters?" Especially where you've got an age range between the children, some maybe want to do different things as they get older.

PS: Yes, that's right! That's the other thing, parents in private law cases, don't seem to understand there is going to come a time when Johnny would rather go to hockey/football on a Saturday morning than spend time with him. Or Suzie wants to go to the youth club with her friends on a Friday night. That's the reality of life. In Lord Justice Gillen's paper, which will form part of the review and will be public, he deals in detail with looking at how we hear, or don't hear, the voice of the child. There's a very strong view that, in every case involving a child, the child should be spoken to. A lot of these cases, the issues I am talking about, you have social workers and lawyers bartering and trying to reach agreement on rates of contact, nobody ever says to the child. I mean it is this child who has to live with these decisions.

SM: That's fantastic, if that's the recommendation coming through because I know that l've been ready for hearings, and they've settled on a barter basis . . .

PS: Yeah.

SM: ... which wasn't maybe the best way to do it, but my cross-examination was going to be, "Why wasn't the child asked? Have you asked this child? Why's that not in the report?" And, I'm thinking, "It's a shame that we've got to the stage of cross-examination about that instead of trying to speak about it earlier." I was saying to the social worker, "Could this not be done?" It just never was. But, it's a good thing, if that's coming through.

PS: Well, I know that Lord Justice Gillen is very, very clear on that as part of his recommendation: the importance of hearing the voice, and we're currently not doing that. The other thing, of course, is that whoever is going to speak to the child needs to have training. Judges in Northern Ireland never, to my knowledge, refuse to see a child, if asked. But, we don't initiate it. We don't initiate it because we're all very nervous about it. I may be the mother of 4 children, but that does not mean that I have the skills and ability to elicit appropriate information from a very damaged child. I am very conscious of that. We all are. So, in terms of how future recommendations are going to be implemented, we're very clear there is a training issue. 
SM: Fantastic!

SR: Exactly!

\section{Attentive or Deep Listening}

SR: You made another really powerful statement at the "Just Listening" symposium. It has formed the basis of many of my articles...

[Laughter]

PS: No pressure then!

SR: . . . and it provoked deep respect from everyone in the audience. I mean they love you!

[Laughter]

SR: The musicians couldn't say enough beautiful, wonderful things about you. But, I wanted to reread your statement and then have you talk about that again in a bit more detail. You say-and think you also mentioned this a bit earlier:

[l]f people genuinely feel that they have been listened to, that the judge has understood their point, that the judge has given them proper consideration, even if they lose, they can deal with it . . . because they have been listened to. . . . And, it is a key task for any judge to not just listen, but to convey the fact to the person that they have been listened to, and, in my own experience in the family court, I think it is an absolute priority that the vulnerable parents are made to feel that they matter, that they are treated with dignity and respect, and I consciously speak directly to parents, for example. I do it deliberately and consciously so that they understand, and very often some of the vulnerable people who find their way into court, they've never been listened to by anyone, they've been treated like a piece of dirt by authorities everywhere all their lives, and, as a judge, I make it a priority that in my court they will not feel like that.

To which Pauline Oliveros-who is the key figure in relation to Deep Listening ${ }^{14}$ _replied, "It's deep listening."

In our Into the Key of Law research project, and our research more generally, we explore improvisation as a social practice, which is a way of being in the world or relating to others that requires, among other things, "an open listening attitude, [or] an openness towards other voices and the voices of others" (Cobussen and Neilsen 10, emphasis added).

As such, I was wondering if you could speak a bit more on what it means to listen openly or respectfully in law, and also how do you think you can evidence to the litigants that they are being listened to? What are the signs of listening?

PS: Body language is key. Eye contact is key. I use my voice very deliberately. I used my voice very deliberately in a lot of different spheres as a judge. In the criminal sphere, for example, very often I am dealing with sexual abuse trials, and where I have a complainant, a person who is making allegations, I am very gentle in the way I introduce myself. Welcome the person. Make eye contact. That's quite deliberate. In the family sphere, again, those same skills. Eye contact. Calling a person by their full name: "Mrs X, what I understand your concern is ..." "Now, what I am looking to see is whether or not I can return Jimmy to you, what is concerning me is ...", whatever it may be. Or "Now, you see, Mrs X, unless I am sure that Jimmy will be safe, as a judge, I can't do what you want me to do. Now, if you do want me to do $X$, you're going to have to show me that you're telling the truth to the social workers when you say that there's nobody staying overnight in your house, or that you haven't been drinking." Speak to them with respect. Also, I will explain in very clear, simple terms what the problems are, so that they build a rapport with me. I mean, I have had a lot of cases, which would be in regularly for various reasons, and I would build a rapport. I think it was enormously important in getting breakthroughs.

I remember, for example, one case, it was a mother who I was very, very, very-I became very fond of herbecause she had had a terrible start in life, terrible start, and she was doing her very, very best to be a mother to two children. No help, of course, from any father. And, she had an anger issue. She had a particular issue with social workers, you know? So, they would come back to court and they would say, "Look, we've tried! And no matter how hard we try, you know, look she spat at me! She actually spat at me." Or, "She started hurling abuse at us!" In that particular case, I was able to build a rapport with her and I was able to explain to her, "Look, if you 
do those kinds of things, this is the result." I remember not every decision went her way. It didn't. In fact, one of her children was with the paternal grandparents in Scotland, but she wanted that child back, and I explained to her ... she had another small one ... "Look, let's make sure that we have everything in place for the new baby that you have. Let's get everything in place, and when we've got all that sorted, then we'll look at getting Suzie back. In the meantime, of course, we needed contact sorted out, which was a very difficult issue. It reached the point where, when I didn't do what she wanted me to do, she could accept it. I could see in her face that she accepted it. It came to the point where, if I said it—I think she said through her lawyers at one stage-if I said it, she would accept it because she felt she was treated fairly. And, she also heard me in the court making sure that if there was anything that could be done, it was done. She could see the justice of it. She didn't get her way all the time, but she did sometimes. So, again, that requires very determined conscious effort.

SR: And, do you think that those sorts of listening, or the signs, the evidence of listening, can actually be taught to judges? Should that become part of the formal training to instil this skill to judges?

PS: Absolutely. In every area of work. It's a very, very important skill. And, it can be taught.

SR: Yes. The things you were evidencing, I mean, those are things you can easily teach, or just make judges aware of.

PS: And, I am sure I have had training in the past. In my former life, I was vice-president of the employment tribunals, and before I was vice-president I was a tribunal chairman, and I sat with two lay people, and a significant number of people would have been litigants-in-person. I did avail of a lot of training, so I'm quite sure that that's based on training that I've had. I'm sure of that.

SR: On that same line, what do you think are the risks or the limitations on that sort of listening in relation to law?

PS: Risks and limitations?

SR: Yes.

PS: I don't think there's any risk in really listening. I can't see any downside in really listening. What had you in mind?

SR: I was thinking more about what we were talking about earlier about resources. Resources in terms of time. To really, truly listen. I mean a lot that I'm reading lately about listening talks-you had mentioned this beforeabout the hard work that has to go into properly listening - and, so, I guess "risk" is probably the wrong word, but the work that goes into listening and how there might just not be enough time.

PS: No. It's not a time issue. It's not a time issue. I mean I could spend all day not listening to people, if I wanted to. Or, I could spend five minutes really listening. So, it's not a time issue, it's a training issue.

\section{Concluding Remarks}

SR: Thank you. Thank you so much, for all your support, and brilliant insights.

PS: I wish you luck in this project. You know what, I feel so much better after our conversation. My colleague, you may not know, Judge Philpott, ${ }^{15}$ who was a family judge, passed away at the end of last week, and she was a very close friend of mine, and passionate about family work. Her funeral was yesterday, and we had a tribute today. So, I had been feeling pretty down in the mouth, but, you know, I feel so much better after our passionate conversation about this issue. Thank you very much.

SR: Thank you! You've given me such hope. We just need more judges like you!

PS: Oh, there are lots of judges like me in Northern Ireland.

SR: That's really promising.

\section{Notes}

${ }^{1}$ For more information, see <www.translatingimprovisation.com/ahrc $>$ 
${ }^{2}$ For more information and video documentation, see Panel 3

$<$ http://translatingimprovisation.com/portfolio/symposium>.

3 This workshop/focus group took place at the Sonic Arts Research Centre (SARC), Queen's University Belfast (QUB) on Friday 14 August 2015.

${ }^{4}$ See Brown and Sheridan.

${ }^{5}$ The Lord Chief Justice of Northern Ireland (NI) announced the launch of a Review of Civil and Family Justice, which is being led by Lord Justice Gillen, at the start of the new legal year on 7 September 2015. The aim of the Review is to look fundamentally at current procedures for the administration of civil and family justice, with a view to:

- $\quad$ improving access to justice;

- $\quad$ achieving better outcomes for court users, particularly for children and young people;

- creating a more responsive and proportionate system; and

- making better use of available resources, including through the use of new technologies and greater opportunities for digital working.

Members of the public were called upon to share their experiences with the Civil and Family Justice Review Group as well as their ideas for how a more modern and responsive system can be created in NI. The Final Report of the Civil and Family Justice Review Group was published in September 2017 and can be found at <https://www.judiciary-ni.gov.uk/sites/judiciary-ni.gov.uk/files/media-files/Family\%20Justice\%20Report\% 20September\%202017.pdf>. For more information, see <https://www.judiciary-ni.gov.uk/civil-and-family-justicereview>.

${ }^{6}$ A pre-proceedings meeting takes place between the local authority (see below), the parents and the parents' lawyer to discuss with the parents how they can change the way they look after their child and what support and help is needed from the local authority. If both sides agree, they will write a formal agreement that both the parents and the local authority have to follow. If parents do not agree to the changes, or do not follow the agreement, the local authority will most likely ask the court to take the child into care. For more information, see <https://www.nspcc.org.uk/preventing-abuse/child-protection-system/northern-ireland/care-proceedings/>.

${ }^{7}$ Local Health and Social Care Trusts or Local Authorities are equivalent to Social Services in Canada.

${ }^{8}$ Article 60 of the Children (Northern Ireland) Order 1995 provides that, in any case involving specified proceedings [specified proceedings are defined in Article 60(6) of the Order], the Court shall appoint a Guardian Ad Litem for the child concerned unless satisfied that it is not necessary to do so in order to safeguard his or her interest. The Guardian Ad Litem shall be appointed in accordance with rules of Court and shall be under a duty to safeguard the interests of the child in the manner prescribed by such rules.

${ }_{9}^{9}$ Article 3(2) of the Children (NI) Order 1995 sets out the No Delay principle: "In any proceedings in which any question with respect to the upbringing of a child arises, the court shall have regard to the general principle that any delay in determining the question is likely to prejudice the welfare of the child."

10 His Honour Judge Brian Sherrard graduated in law from Queen's University Belfast (QUB) in 1991. He was called to the Bar in September 1992 and remained in private practice until 1998. In 1995 he became a lecturer in Property Law at QUB. From 1998 until 2006 Judge Sherrard was the Legal Secretary to the Lord Chief Justice of Northern Ireland and from 2004 until 2006 was also the Secretary to the Judicial Studies Board of Northern Ireland. Judge Sherrard was appointed as a Coroner in April 2006 until September 2012 when he was appointed as a County Court Judge.

${ }^{11}$ A care order made by a court puts a child under the care of a local Health and Social Care (HSC) Trust, which then share parental responsibility for the child with the parents and gives it the power to make most of the important decisions about the child's upbringing, such as where they live and go to school.

12 Women's Aid Federation of Northern Ireland is a voluntary organisation addressing domestic and sexual violence and providing services for women and children.

According to its website:

Journey to Freedom is a personal development group process, for women who have 
experienced domestic violence. It provides a safe and supportive group process to enable women to explore their experiences of domestic violence and to empower them to move on.

It was adapted from a model widely used throughout Canadian refuges and was initially developed by staff in North Down and Ards Women's Aid. Over the years, the programme has proved to be an exceptional tool in assisting women to recognise patterns that exist within abusive relationships. As a result the Journey to Freedom process has been rolled out across Women's Aid groups in Northern Ireland.

For more information, see <https://www.womensaidni.org/get-help/local-groups/journey-to-freedom/>.

${ }^{13}$ According to Article 50(2) of the Children (NI) Order 1995, "A court may only make a care or a supervision order if it is satisfied (a) that the child concerned is suffering, or is likely to suffer, significant harm; and (b) that the harm, or likelihood of harm, is attributable to (i) the care given to the child, or likely to be given to him if the order were not made, not being what it would be reasonable to expect a parent to give to him; or (ii) the child's being beyond parental control." This is often referred to as the "Threshold Test."

14 "Deep Listening" is a philosophy and practice developed by Pauline Oliveros, which "explores the difference between the involuntary nature of hearing and the voluntary, selective nature-exclusive and inclusive-of listening. . . . It cultivates a heightened awareness of the sonic environment, both external and internal, and promotes experimentation, improvisation, collaboration, playfulness and other creative skills vital to personal and community growth." For more information, see <http://www.deeplistening.org/site/content/about>.

Video documentation of Pauline Oliveros's keynote address, "Safe to Play," given at the "Just Improvisation" Symposium on 30 May 2015, can be accessed at <http://translatingimprovisation.com/portfolio/symposium>. Pauline Oliveros died on 24 November 2016 at her home in Kingston, NY. She was 84.

15 Judge Corinne Philpott QC, the first female judge in Northern Ireland, was called to the Bar in December 1977 and took silk in December 1993. She was appointed a County Court judge in April 1998 and was Recorder of Derry/Londonderry from March 2002 until January 2008, in 2012 becoming Deputy Recorder of Belfast. Judge Philpott died age 62 on 16 June 2016 after a long illness.

\section{Works Cited}

Brown, David and Danielle Sheridan. “Judge backed father who went on to murder girl." The Times 22 June 2016, http://www.thetimes.co.uk/article/judge-backed-father-who-went-on-to-murder-girl-33s7cj0mq.

Civil and Family Justice Review Group (Northern Ireland). Review Group's Report on Family Justice. Belfast: Office of the Lord Chief Justice, 2017, https://www.judiciary-ni.gov.uk/sites/judiciaryni.gov.uk/files/media-files/Family\%20Justice\%20Report\%20September\%202017.pdf.

Cobussen, Marcel and Nanette Nielsen. Music and Ethics. Ashgate, 2012.

Oliveros, Pauline. "Harmonic Anatomy: Women in Improvisation." The Other Side of Nowhere: Jazz, Improvisation, and Communities in Dialogue, edited by Daniel Fischlin and Ajay Heble. Wesleyan UP, 2004, pp. 50-70.

Siddall, Gillian. "'I Wanted to Live in that Music:' Blues, Bessie Smith and Improvised Identities in Ann-Marie MacDonald's Fall on Your Knees." Critical Studies in Improvisation / Études critiques en improvisation vol. 1, no. 2, 2005, http://www.criticalimprov.com/article/view/16/46.

Waterman, Ellen. "Naked Intimacy: Eroticism, Improvisation, and Gender." Critical Studies in Improvisation / Études critiques en improvisation, vol. 4, no. 2, 2008, http://www.criticalimprov.com/article/view/845/1396. 